\title{
PRINCIPAL OBJECTIVE AND SUBJECTIVE FACTORS THAT DETERMINE CORRUPTION
}

\section{Tsilmak O. M.}

\section{INTRODUCTION}

Nowadays, on the stage of democratic state development the counterstand and prevention of corruption have great significance. To provide it, Ukraine holds on the course of implementation of anticorruption policy, the chief fundaments of which are legislated in The Constitution of Ukraine and in the Law of Ukraine "On Prevention of Corruption" and in the international treaties that are obligatory according to the consent of Verknovna Rada of Ukraine and in another regulatory legal acts.

Scientific foundation of directions, means and methods of corruption prevention is represented in numerous treatises. Thus, there were widely covered by the scientists: modern problems of fight against corruption (Kulakovskiy R., 2005); issues of state and legal mechanism of corruption counterstand (Besdolniy M., 2009); instruments of corruption counterstand in community arsenal - from fight against corruption to prevention of corruption (Khmara O., 2010) etc.

There were also represented by scientists the issues concerning: peculiarities of corruption's factors influence on economical development of state (Andrei Shleifer, Robert W. Vishny., 1993); causes and factors of corruption and its influence on economy (Verstiuk S., 2001); causes and factors of corruption origin and fight against it (Didenko D., 2010); causes and factors of extension and mechanisms of fight against it (Driomov S., Kalnish Y., 2010) etc.

Scientists distinguished objective and subjective factors are lied at the root of the causes of corruption and it's a condition for corruption activities (Yatskiv I., 2008; Shediy M., 2012 etc.). The group of objective factors consists of: political, economical, legal, organizational and administrative, social and psychological, historical ones (Beliaev N., Volgareva I., Kropachev N., 1992'; Andrei Shleifer, Robert W. Vishny., 1993²; Christos

\footnotetext{
${ }^{1}$ Криминология: учебник / Н.А. Беляев, И.В. Волгарева, Н.М. Кропачев и др.; под ред. В.В. Орехова. СПб.: Издательство С.-П.б ун-та, 1992. 216 с.

${ }^{2}$ Andrei Shleifer, Robert W. Vishny. Corruption. The Quarterly Journal of Economics, Volume 108, Issue 3, August 1993, Pages 599-617,
} 
Pantzalisa, Jung Chul Parkb., NinonSuttona., 2008³; Yatskiv I., 2008 Driomov S., Kalnish Y., $2010^{5}$ etc.). Subjectives factors include moral and spiritual values, moral degradation, deviant behavior, legal nihilism. (Didenko D., 2010 ${ }^{6}$; Yeriomina O., $2017^{7}$ etc.).

There is scientific opinion that inclination to corruption behavior is determined by individual corruptional directivity of a person. M. Danchuk supposes that inclination to corruption behavior "...is reflected by characterological features: inability to separate ideal and real purposes, naivety and frankness that don't correspond to age; egocentrism; formal attitude to the process of fulfilment of official duties and rules of subordination; unwillingness and incapability to predict the possibility of future negative consequences; excessive touchiness, inclination to abrupt mood swing; lack of spiritual development; priority of material values; necessity in pleasure; energy; aspiration for authority and money; inclination to risk; aggressiveness; callousness, indifference, jealousness, touchiness, vindictiveness, ambitiousness, avarice, absence of self-criticism, careerism..." (Danchuk M.D., 2007).

There are scientists that distinguish certain types of corruptionists, for example O. Shostko ${ }^{9}$ describes such types as: "minor corruptionst" (situated type), ordinary corruptionist (representative of corruption system), initiative

${ }^{3}$ Christos Pantzalisa,Jung Chul Parkb. Corruption and valuation of multinational corporations/ Christos Pantzalisa, Jung Chul Parkb., NinonSuttona., Journal of Empirical Finance. Volume 15, Issue 3, June 2008, Pages 387-417 https://doi.org/10.1016/ j.jempfin.2007.09.004

4 Яцків I. I. Механізм, причини та заходи протидії корупції: загальна характеристика / I. І. Яцків // Держава $і$ закон: теорія, практика, методика : зб. наук. пр. Івано-Франківськ : ПЮІ ЛьвДУВС, 2008. Вип. 3. С. 155-163.

5 Дрьомов С. В. Корупція в Україні : причини поширення та механізми протидії / С. В. Дрьомов, Ю. Г. Кальниш; за ред. Ю. Г. Кальниша. К.: ДП "НВЦ "Пріоритети", 2010. 88 c.

6 Диденко Д.А. Причины возникновения коррупции и борьба с ней. // Международный журнал прикладных и фундаментальных исследований. 2010. № 3. C. 55-55. URL: https://applied-research.ru/ru/article/view?id=430 (дата обращения: 14.08.2019).

7 Еремина О.С. Коррупция: источники, причины, социально-негативные последствия. Т. 18., URL: http://www.pglu.ru/upload/iblock/674/pages-from-chast-9_18.pdf

8 Данчук М.Д. Психологічні особливості виникнення і подолання корупційного делікту правоохоронців. // автореф. дисертації на здобуття наукового ступеня кан-та психол. наук за спеціальністю 19.00.09 "Психологія діяльності в особливих умовах". Національна академія Прикордонної служби України імені Богдана Хмельницького. Хмельницький, 2007. 21 с.

${ }^{9}$ Шостко О. Типологія осіб, які вчиняють корупційні злочини Транскордонна співпраця: проблеми та шляхи їх вирішення: матеріали Т 65 II Регіонального круглого столу (28-29 вересня 2017 року). К.: Національна академія прокуратури України, 2017. C. 203-205. 
corruptionist (malicious), peculiarly malicious (political) corruptionist (Shostko O., 2017). O. Litvinova ${ }^{10}$ - usual bribetaker and bribetaker of nonpersistence type (Litvinova O., 2015).

So, it is possible to conclude, that there are many scientific works that contain the investigation of general fundaments of corruption, the mechanisms of its development, cause and factors. Nevertheless, the most significant for us are objective and subjective factors, that exist in Ukrainian community and upon the whole may determine corruption.

\section{Methodological basis of scientific research}

The purpose of our scientific research is to establish the level of involvement of principal objective factors of the process of development and existence such negative phenomenon as corruption in Ukrainian community and also to determine and to concretize subjective factors (psychological characteristics), that are supposed to be indicators of personal corruption behavior and determine certain corruptionists' type.

To achieve mentioned purpose there were formulated such tasks as to:

- establish scientifically the level of principal objective factors involvement on the process of development and existence of corruption;

- establish if there any differences in opinions of police officers and civil people about the level of involvement of principal objective factors on corruption;

- concretize principal subjective factors (psychological characteristics) that are supposed to be indicators of person's corruption behavior and determine certain corruptionist's type;

- classify the types of corruptionist.

The object of our scientific research were social relations. The subject of investigation are objective and subjective factors, that determine the process of development and existence such negative phenomenon as corruption in Ukrainian society.

We have used a complex of the following methods in our scientific research: general-scientific (general-logical and general-theoretical), polling, mathematical and empirical methods. By means of general-logical (analysis, synthesis, induction, deduction, scientific abstraction, generalization, analogy, modelling, classification) and general-theoretical (formalization, axiomatic, hypothetic-deductive) methods there were: a) concretized objective and subjective factors of corruption; в) classified the types of corruptionists and specialized their psychological characteristics.

${ }^{10}$ Кримінологія: питання та відповіді / за заг. ред. О. М. Литвинова. Харків : Золота миля, 2015. 324 c. 
Thus, by means of the worked out questionnaire (about objective factors, that exist in Ukrainian society and determine corruption phenomena) there were questioned police officers of National police of Ukraine and citizens (hereinafter - respondents). There were 651 respondents that took part in the questioning, among them -368 respondents were police officers of Chief office of National police of Ukraine in Odesa region (Odesa city, Ukraine) and 283 respondents were citizens (individuals).

Applying mathematical methods (calculation, registration, scaling,) there were: a) calculated the results of respondents questioning; в) carried out the ranging of basic indexes; c) established the types of corruptionists; d) determined the level of involvement of objective factors on corruption. By means of empirical methods (comparison and description), there were represented basic results of scientific research.

Having analyzed scientific resources we were determined that there are different principal and secondary objective and subjective factors of corruption. We have chosen only principal factors for our research and we have grouped them together in such way:

1) objective - political, economical, legislative, organization and managerial, social and psychological;

2) subjective (psychological characteristics) - motivational, volitional, moral, emotional, features of character.

The scientific research was carried out in several stages, that is to say we have:

1) proposed the respondents to complete anonymous questionnaire about the impact level of objective factors (that exist in Ukrainian society) on the process of development and existence of corruption (according to three criteria - high impact level, middle and low);

2) questioned the respondents about types of corruptionists and inherent psychological characteristics;

3) processed statistically the results of scientific research and determined tendencies and peculiarities;

4) proved principal scientific fundaments about groups of principal objective and subjective factors of corruption.

\section{The results of empirical research}

Thus, there were determined during empirical research, the impact level of principal objective factors (political, economical, legislative, organization and managerial, social and psychological) on the process of development and existence in Ukrainian society such negative phenomena as corruption. 
So, concerning existence in Ukrainian society principal political factors and the level of its influence on corruption. According to the respondents' opinions:

1) complexity of governmental structure of bureaucracy procedure has:

- high level impact $-80 \%$ of police officers and $90 \%$ of citizens;

- middle level impact - $20 \%$ of police officers and $10 \%$ of citizens;

2) superficiality in process of carrying out anticorruption policy has:

- high level impact $-69 \%$ of police officers and $90 \%$ of citizens;

- middle level impact $-31 \%$ of police officers and $10 \%$ of citizens;

3 ) unwillingness of political elite to provide non-corruptive style of behavior in authoritative activity has:

- high level impact- $97 \%$ of police officers and $100 \%$ of citizens;

- middle level impact $-3 \%$ of police officers;

4) incoherence during the process of social transformations has:

- high level impact - for all of the respondents;

5) lack of efficient parliament and public control for chief executive officers including directors of law-enforcement agencies has:

- high level impact - $87 \%$ of police officers and $100 \%$ of citizens;

- middle level impact $-13 \%$ of police officers;

6) lack of proper political volition about resolute delimitation political activity from business has:

- high level impact - for all of the respondents;

As we may observe, according to the result of the questioning, the respondents unanimously confirm such factors as: "incoherence during the process of social transformations" and "lack of proper political volition about resolute delimitation political activity from business" have high level impact on development of corruption in Ukrainian society. As for another factors, we may conclude that there are differences between opinions of police officers and citizens, but the majority of them approve the indexes to have high level impact. Thus, according to the results of research it was determined, that certain peculiarities of political situation in Ukrainian society influence in direct proportion to the existence of corruption in state.

Talking about principal economic factors of corruption. All respondents (either police officers or citizens are one hundred percent confident, that in Ukrainian society there are such factors as: "lack of transparency of different economical processes", "underdevelopment of small and medium business", "lack of conductive regime for proper activity of enterprises and entrepreneurs, especially about taxes payment, allotments, getting state support, credits etc"., "decrease of living standards, that corresponds with unemployment", "low level of payment for labor", "wage non-payment", "deprivation of social benefits", "increase the quantity of wealthy and rich 
people", "unstable economical situation", - these factors exist and have high level impact on the process of development and existence of corruption.

As for such factor as "lack of transparency of processes of property privatization, decision of different economic issues, evaluation of incomes, amount of taxes, getting benefits etc"., respondents' opinions are different, but the majority of them are confident, that cited factor exists in Ukrainian society and it also has high level impact on the process of development and existence of corruption (87\% police officers and $99 \%$ citizens).

So, the process of corruption overcoming in Ukrainian society depends in direct proportion to economic welfare of state.

As for the principal legal factors of corruption. There were concluded, that opinions of respondents about high level impact on the process of development and existence of corruption totally coincide about: "lack of integral system of anti corruption means" and "inefficiency of anticorruption means' system". As for such factor as "imperfection of laws in corruption counterwork field" there were determined differences in opinions of police officers and citizens. Citizens one hundred percent confident, that cited factor exists in the state and has a high level impact on corruption phenomena existence, but only $22 \%$ police officers support this point of view.

$100 \%$ of citizens are one hundred percent confident, that in Ukrainian society there is such factor as - "lack of legal mechanism of prevention and resolving the conflict of interests", that also has high level of impact on development and existence of corruption, but only $27 \%$ police officers support this opinion. An explanation of this lies in legal awareness about statutory and regulatory maintenance of state policy in corruption counterwork field.

\section{Principal organization and managerial factors of corruption.} Respondents are one hundred persent confident, that such factors as "possibility for officials to make decisions in their absolute discretion", "inequitable separation national income among different population stratums", "poor level of social services provision", "existence of bureaucratic institutions of soviet type", "lack of control for personnel policy" and "poor quality and groundlessness of managerial decisions" exist in Ukrainian society and have high influence on the process of development and existence of corruption.

The results of police and citizens questioning contain differences. Thus, there is one hundred percent confidence of citizens, that, high level of impact on corruption have such factors as: "existence in personnel policy cases of filing state servants positions by means of using personal relation (but only $63 \%$ police officers support this opinion)", "lack of real influence of nongovernmental organizations on the state of affairs in corruption counterwork 
field" (but only 97\% police officers support this opinion) and "impaired control for fulfilment by civil servants the laws and other legal acts and executives orders" (only $6 \%$ of police officers - an explanation of this lies in low indexes according to this factor, that indicates police officers activity to be sharply defined and controlled).

Principal social and psychological corruption factors. Respondents are one hundred percent confident, that in Ukrainian society there are such factors as: "spreading of society demoralization", "devaluation of moral values", "mentality of people" (readiness to pay additional money to solve their problems), "capability to solve any issue without any efforts and waste of time", "distorted mentality" and "transformation of corruption relations into social norm (rule of behavior)" - have a great level of impact on existence of corruption.

As for another factors, it is worth mentioning those results to be different. So, citizens are one hundred percent confident, that in Ukrainian society exist and have a great level of impact such principal social and psychological factors as: " lack of efficient public control for the activity of public authorities and agencies of local self-government, their officials, political and public figures" (whereas only $12 \%$ of police officers support this opinion an explanation of this lies in police officers activity to be sharply defined and controlled) "positive attitude of publicity towards existence of corruption" (whereas only $84 \%$ of police officers support this opinion), "rejection of corruption as social evil" (whereas only $56 \%$ of police officers support this opinion), "mercenary purposefulness of public servants", (whereas only $82 \%$ of police officers support this opinion), "avoidance of objective cross-light of corruption issues" (whereas only $49 \%$ of police officers support this opinion) and "professional and moral distortion of certain supervisors, that appears in incentive attitude towards corruption" (whereas only 54\% of police officers support this opinion).

As for another social and psychological factors, that exist in Ukrainian society and determine corruption phenomena, respondents opinions tend to be different. Thus, according to their opinion such factor as:

1) Underdevelopment of civic awareness has:

- high level impact $-100 \%$ of police officers and $54 \%$ of citizens;

- medium level impact $-24 \%$ of citizens;

- low level impact $-22 \%$ of citizens.

Such indexes tell us that certain citizens tend to accuse others in corruption relations, that to affirm about underdevelopment of civic awareness.

2) Double-sided corruption interest:

- high level impact $-100 \%$ of police officers and $32 \%$ of citizens;

- medium level impact $-68 \%$ of questioned citizens. 
An explanation of this lies in that police officers have to work with group of people, that on the one hand don't want to be responsible for their own acts, and on the other one - they tend to solve their issues by means of improper advantage. That's why, according to the opinion of police officers, there is double-sided corruption interest. Citizens tend to suppose them to be the victims of corruption relations, without recognizing them to belong to such relations.

3) Slackening of society immune against corruption (that is loyalty and toleration to it) has:

- high level impact $-24 \%$ of police officers and $25 \%$ of citizens;

- medium level impact $-46 \%$ of police officers and $58 \%$ of citizens;

- low level impact - $30 \%$ of police officers and $17 \%$ of citizens.

These indexes tell about constant struggle corruptionists in agencies and departments of National police. Citizens don't want to accept their own loyalty to corruption, although they sometimes have to solve different issues by means of improper advantage.

4) Disillusionment of a major part of population in seriousness of measures to struggle against corruption and of possibility of tangible positive changes in this area, has:

- high level impact $-28 \%$ of police officers and $97 \%$ of citizens;

- medium level impact $-45 \%$ of police officers and $3 \%$ of citizens;

- low level impact $-27 \%$ of police officers.

These indexes tell us that police officers are more knowledgeable about the issues of corruption counterwork state policy.

To sum it up, it should be noted, that principal objective factors in general have high impact level on the process on development and existence of corruption in Ukrainian society. The process of corruption overcoming depends on in direct proportion to economic welfare of the state, political volition, legal initiatives, organizational and managerial measures, social and psychological conditions.

It is understandable, that objective factors, that determine corruption are interrelated with subjective ones. It is necessary to emphasize, that subjective factors are briefly described by scientists. That's why there were questioned respondents about the types of corruptionists and their principal psychological characteristics (subjective factors of corruption). Having analyzed, systematized and generalized the results of our scientific research, there were distinguished by us seven types of corruptionists, they are needy, forced, due to situation, "merchant", "player", mercantilist and cleptocratic. Let's consider their characteristics.

Needy corruptionist type - he is incited to corruption by difficult life circumstances and he would have never risked to accept improper advantage 
for his services being in other situation. There are such psychological characteristics for this type:

1) motivational - desire to overcome material difficulties, ambition to solve the most significant material issues etc.;

2) volitional - incapability to resist of seducing to get improper advantage for service etc.;

3) emotional - feeling of uncertainty in future, disappointment about better future, experience of frustration, desperation etc.;

4) character trait - depend on circumstances and other individuals.

Forced corruptionist type, according to typology of O. Shostko, - it is an ordinary corruptionist (representative of corruption system). He is also as needy type doesn't become corruptionist due to his own initiative. "...He just keeps "rules of the game", that were established in certain organization or agency. He displays, by means of his acts, loyalty to the system, that is also called "corporative culture". He is a conformist. These subjects usually share their incomes with their director (directors)..."

There are such psychological characteristics for this type, as:

1) motivational - intention to fulfill the demand of administration, desire to stay at work, to solve certain material issues, to please and to move up the career ladder etc.;

2) volitional - incapability to resist the requirements of certain significant person or certain circumstances; incapability;

3) emotional - retorted feeling of debt, obligation, feeling of instability and etc.;

4) moral - high executive discipline about fulfillment of directors orders or demands of relatives, retorted responsibility for consigned job area, moral and psychological unwillingness to resist corruption and etc.;

5) character traits- obedience, conformity, dependence on other people and circumstances and etc.

As for the corruptionist type due to situation, it should be noted that according to the typology of O. Shostko - he is "small corruptionist" (situational type). This type during certain period of his life couldn't resist of seducing improper advantage for his services. These individuals don't require bribe for their services, they are satisfied with episodic remunerations, as symbols of gratitude for their job. They sometimes receive improper advantage "...in minor amounts (besides money there are may be

11 Шостко О. Типологія осіб, які вчиняють корупційні злочини Транскордонна співпраця: проблеми та шляхи їх вирішення: матеріали Т 65 II Регіонального круглого столу (28-29 вересня 2017 року). К.: Національна академія прокуратури України, 2017. C. 203-205. 
goods or products) in case to solve daily living problem of members of the public..."12. There are such psychological characteristics for this type, as:

1) motivational - intention to make better life, desire to improve economic condition and etc.;

2) volitional - situation capability to resist seducing to get improper advantage for proper services and etc.;

3) emotional - feeling of uncertainty in the future and etc.;

4) moral - moral and psychological unwillingness to resist corruption, moral control is not developed enough and etc.

"Merchant" - this type of corruptionist, on the one hand like earning additional money and he intends to have such income, but from the other hand he is afraid of so called "fast bucks". These individuals are adventurous and creative. So, there are such psychological characteristics for this type, as:

1) motivational - willing to live better, desire to improve economic condition and etc.;

2) volitional - situation capability to resist seducing to get improper advantage for proper services and tendency to risk;

3) emotional - feeling of uncertainty in the future, tendency to adrenaline buzz and etc.;

4) moral - low level of legal conciseness, moral and psychological unwillingness to resist corruption, moral control is not developed enough and etc.;

5) character traits - adventurism, pragmatism, rationality, pushfullness and creativity and etc.

"Player" - he tends to risk analyzing different combinations. Getting of improper advantage is peculiar play, where are winners and losers. They enjoy the process of this "game". Among these types there so called "clean fighters" and unfair players (swindlers or sharpers). There are such psychological characteristics for this type, as:

1) motivational - aspiration to play, to risk, desire to live better and etc.;

2) volitional - tendency to risk and to adrenaline buzz, courage, decisiveness, purposefulness, initiativity;

3) emotional - feeling of drive from the risk and etc.;

4) moral - low level of legal conciseness, moral self-control is weakly developed, dishonesty and etc.;

${ }^{12}$ Шостко О. Типологія осіб, які вчиняють корупційні злочини Транскордонна співпраця: проблеми та шляхи їх вирішення: матеріали Т. 65. II Регіонального круглого столу (28-29 вересня 2017 року). К.: Національна академія прокуратури України, 2017. C. 203-205. 
5) character traits - adventurism, pushfullness and creativity and etc.

Mercantilist corruptionist type - he has become corruptionist due to his own desire and according to surrounding he attitudes with mercantile. This type constantly generates and realize different corruption schemes, he is looking for his own advantage. There are such psychological characteristics for this type, as:

1) motivational - aspiration to improve economic condition using money of others, desire to live better; to become rich, intention to get power and money, necessity for pleasure and etc.;

2) volitional - incapability to resist of seducing to get improper advantage, incapability to resist of seducing of own enrichment, tendency to risk, courage, purposefulness, initiativity and etc.;

3) emotional - feeling of corruption impunity, arrogance, mistrust in efficiency of supremacy of law principle and etc.;

4) moral characteristics - poor moral values, low level of legal consciousness, legal nihilism, improper responsibility for quality and results of activity, weakly developed moral self-control of behavior, impudence, arrogance, cowardice and etc.;

5) character traits - mercantilism, avarice, egocentrism, ambitiousness, careerism, pushfullness, creativity, unreliability and etc.

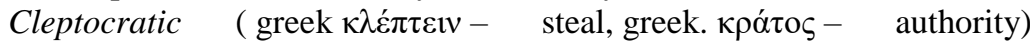
corruptionist type belongs to certain authority link and use official position for personal enrichment, there is passionate thirst for enrichment and for getting a profit, he seems to be possessed of "thirst for enrichment". There are such psychological characteristics for this type, as:

1) motivational - passionate desire to become rich, aspiration to become wealthy (mean is not important); passionate thirst to authority and money, pleasures and etc.;

2) volitional- tendency to risk and to adrenaline buzz, incapability to resist of seducing to get improper advantage, passionate money addiction, courage, purposefulness, initiativity and etc.;

3) emotive - feeling of corruption impunity, arrogance, personal advantage, omnipotence, permissiveness and etc.;

4) moral characteristics - immoral values, priority of material values, legal nihilism, impudence, insolence, heartlessness, indifferent to problems of others and etc.;

5) character traits - impudence, insolence, mercantilism, omnipotence, avarice, egocentrism, aggressiveness, jealousness, ambitiousness, adventurism, pushfullness, unreliability and etc.

So, the subjective factors (psychological characteristics) are the indicators of personal corruption behavior and determine certain type of 
corruptionist. Disclosing of principal psychological characteristics of certain corruptionists types will provide extension and concretization diagnostic criteria to recommend candidate on the position (especially governing).

According to our research, types of corruptionists that were distinguished by us should be added by two types, that were determined O. Shostko ${ }^{13}$, that is - initiative (uncharitable type) of corruptionist and especially uncharitable (political) corruptionist (Shostko O., 2017). We should mention, that types of corruptionists that were described by us are not final. Nevertheless, they add another typologies and extent the boarders for further scientific and practical researches.

Research scientific novelty. According to empirical research applied methodological instruments there were: a) classified corruptionists' types (needy, forced, corruptionist type due to situation, "merchant", "player", mercantilist and cleptocratic) and determined their principal pschylogical characteristics (motivational, volitional, moral, emotive, character traits); b) there was carried out empirical research of impact level of exited in Ukrainian society objective factors (political, economical, legislative, organization and managerial, social and psychological), that in general determine corruption.

Thanks to our scientific research there have got the further development: a) impact level of objective factors on the process of development and existence of corruption; b) subjective factors (motivational, volitional, moral, emotive, character traits), that are indicators of personal corruption behavior.

\section{CONCLUSIONS}

1. During the process of empirical research there was determined, that there are political, economical, legislative, organization and managerial, social and psychological factors in Ukrainian society and that generally have high impact level on the process of development and existence such negative phenomena as corruption.

2. There were emphasized certain differences in opinions of police officers and citizens about impact level of objective factors on the process of development and existence of corruption. An explanation of this lies in such directions: a) police officers are more knowledgeable about the issues of corruption counterwork state policy and about laws, that regulate anti

13 Шостко О. Типологія осіб, які вчиняють корупційні злочини Транскордонна співпраця: проблеми та шляхи їх вирішення: матеріали Т 65 II Регіонального круглого столу (28-29 вересня 2017 року). К.: Національна академія прокуратури України, 2017. C. 203-205. 
corruption policy of Ukraine; police officers activity to be sharply defined and controlled; b) citizens - tend to accuse others in corruption activities (although there is double-sided corruption characteristic) and considers them being victims of corruption relations, that their participants.

3. Based on results of respondents questioning there were classified such type of corruptionists as: a) needy (he is incited to corruption by difficult life circumstances); в) forced (he is incited to corruption by "corporate culture", or a significant person (director or relatives); c) corruptionist type due to situation (these individuals don't require bribe for their services, they are satisfied with episodic remunerations, as symbols of gratitude for their job); d) "merchant" ( on the one hand he likes earning additional money and he intends to have such income, but from the other hand he is afraid of so called "fast bucks", but at the ends he risks); e) "player" (he tends to risk, analyzing different combinations, getting of improper advantage is peculiar play. Among these types there so called "clean fighters" and unfair players (swindlers or sharpers); f) mercantilist (express his mercantile attitude, generate and realize different corruption schemes); g) cleptocratic (belongs to certain authority link and use official position for personal enrichment, there is passionate thirst for enrichment and for getting a profit).

4. It was specialized principal subjective factors, that are indicators of corruption behavior of a person and determine certain type of corruptionist. They contain such psychological characteristics as: motivational, volitional, moral, emotive, character traits. Disclosing of principal psychological characteristics of certain corruptionists types will provide extension and concretization diagnostic criteria to recommend candidate on the position (especially governing).

5. It was emphasized, that the process of corruption overcoming depends on in direct proportion to economic welfare of the state, political volition, legal initiatives, organizational and managerial measures, social and psychological conditions and the quality of professional and psychological selection of applicants on proper position (especially governing).

\section{SUMMARY}

Nowadays, on the stage of democratic state development the counterstand and prevention of corruption have great significance. To provide it, Ukraine holds on the course of implementation of anticorruption changes.

The purpose of our scientific research is to establish the impact level of principal objective factors of the process of development and existence such negative phenomenon as corruption in Ukrainian community and also to 
determine and to concretize subjective factors (psychological characteristics), that are supposed to be indicators of personal corruption behavior and determine certain corruptionists' type.

During the process of empirical research there was determined, that there are political, economical, legislative, organization and managerial, social and psychological factors in Ukrainian society and that generally have high impact level on the process of development and existence of corruption.

There were emphasized certain differences in opinions of police officers and citizens about impact level of objective factors on the process of development and existence of corruption. An explanation of this lies in such directions: a) police officers are more knowledgeable about the issues of corruption counterwork state policy and about laws, that regulate anti corruption policy of Ukraine; police officers activity tends to be sharply defined and controlled. Citizens - tend to accuse others in corruption activities (although there is double-sided corruption characteristic) and considers them being victims of corruption relations, that their participants.

Based on results of respondents questioning there were classified seven types of corruptionists as: a) needy; в) forced; c) corruptionist type due to situation; d) "merchant"; e) "player"; f) mercantilist; g) cleptocratic and for each type there were specialized their principal psychological characteristics: motivational, volitional, moral, emotive, character traits.

It was emphasized, that the process of corruption overcoming depends on in direct proportion to economic welfare of the state, political volition, legal initiatives, organizational and managerial measures, social and psychological conditions and the quality of professional and psychological selection of applicants on proper position (especially governing).

\section{REFERENCES}

1. Бездольний М. Ю. Державно-правовий механізм протидії корупції / М. Ю. Бездольний // Форум права. 2009. № 2. С. 38-43. URL: http://www.nbuv.gov.ua/e-journals/FP/2009- 2/09bmympk.pdf 7

2. Верстюк С. Корупція: визначення, причини появи, вплив на економіку / С. Верстюк // Економіка України. 2001. № 3. С. 66-74.

3. Данчук М.Д. Психологічні особливості виникнення і подолання корупційного делікту правоохоронців. // автореф. дисертації на здобуття наукового ступеня кан-та психол. наук за спеціальністю 19.00 .09 „Психологія діяльності в особливих умовах”. Національна академія Прикордонної служби України імені Богдана Хмельницького. Хмельницький, 2007. 21 с.

4. Диденко Д.А. Причины возникновения коррупции и борьба с ней. // Международный журнал прикладных и фундаментальных 
исследований. 2010. № 3. C. 55-55. URL: https://applied-research.ru/ ru/article/view?id=430 (дата обращения: 14.11.2019).

5. Доля Л. М. Причини корупції в Україні та іï наслідки для суспільства / Л. М. Доля // Боротьба з організованою злочинністю та корупцією : матеріали наук.-практ. конф., 4-5 квіт. 2000 р., Київ. К. : Ред.-вид. відділ МВС України, 2001. С. 104-111.

6. Дрьомов С. В. Корупція в Україні : причини поширення та механізми протидії / С. В. Дрьомов, Ю. Г. Кальниш; за ред. Ю. Г. Кальниша. К.: ДП “НВЦ “Пріоритети”, 2010. 88 с.

7. Еремина О. С. Коррупция: источники, причины, социальнонегативные последствия. T. 18., URL: http://www.pglu.ru/upload/ iblock/674/pages-from-chast-9_18.pdf

8. Камлик М. I. Корупція в Україні / M. I. Камлик, Є. В. Невмержицький. К. : Знання, 1998. 179 с.

9. Криминология: учебник / Н. А. Беляев, И. В. Волгарева, Н. М. Кропачев и др.; под ред. В. В. Орехова. СПб.: Издательство С.-П.б ун-та, 1992. 216 с.

10. Кримінологія : підручник / за ред. В. В. Голіни, Б. М. Головкіна. Харків : Право, 2014. 440 с.

11. Кулаковський Р. Сучасні проблеми боротьби 3 організованою злочинністю та корупцією / Р. Кулаковський // Юридичний журнал. 2005. № 6. URL: http://www.justinian.com.ua/article.php?id=1777

12. Хмара О. Нові інструменти протидії корупції в арсеналі громадськості - від боротьби 3 корупціонерами до запобігання корупції / О. Хмара // Громадянське суспільство. 2010. № 2 (13). URL: http://www.ucipr.kiev.ua/modules.php?op=modload\&name=News\&file=arti cle $\&$ sid $=603277232 \&$ mode $=$ thread\&order $=0 \&$ thold $=0$

13. Шостко О. Типологія осіб, які вчиняють корупційні злочини. // Транскордонна співпраця: проблеми та шляхи їх вирішення: матеріали T 65 II Регіонального круглого столу (28-29 вересня 2017 року). К.: Національна академія прокуратури України, 2017. С. 203-205.

14. Яцків I. I. Механізм, причини та заходи протидії корупції: загальна характеристика / I. I. Яцків // Держава $i$ закон: теорія, практика, методика : зб. наук. пр. Івано-Франківськ : ПЮІ ЛьвДУВС, 2008. Вип. 3. С. $155-163$.

15. Шедий M. В. Социальные детерминанты коррупции в Российском обществе. Орел :Изд-во ОФ РАНХиГС, 2012. С. 13.

16. Andrei Shleifer, Robert W. Vishny. Corruption. The Quarterly Journal of Economics. Volume 108, Issue 3, August 1993, Pages 599-617. https://doi.org/10.2307/2118402 
17. Christos Pantzalisa,Jung Chul Parkb. Corruption and valuation of multinational corporations/ Christos Pantzalisa, Jung Chul Parkb., NinonSuttona., Journal of Empirical Finance. Volume 15, Issue 3, June 2008. Pages 387-417 https://doi.org/10.1016/j.jempfin.2007.09.004

\section{Information about the author:}

Tsilmak O. M.,

Doctor of Juridical Sciences, Professor, Professor at the Department of Sociology and Psychology, National university "Odessa Law Academy" 17, Armiys'ka str., Odesa, 65058, Ukraine 